\title{
Does Migration Reduce the Household Poverty in Nepal?
}

\author{
Ramesh Prasad Adhikari \\ Faculty Associate of Padma Kanya Multiple Campus, Tribhuvan University, \\ Kathmandu and Research Co-coordinator of Transcultural Psychosocial Organization (TPO) Nepal,
}

\begin{abstract}
Migration is both cause and consequence of poverty. In some parts of the world, poverty is the root cause of migration, whereas in other parts, the poor are among the last to move. This study tries to explore the impact of migration of any member of the households in the per capita consumption expenditure and the socio-economic status of the households by using Poverty Alleviation Fund household survey: 2010/11, which covered 3000 households from Humla, Jumla, Rolpa, Doti, Dailekh and Rauthat. The study used quasi-experimental research design and poverty was measured by using the same procedure employed by Nepal Living Standard Survey (NLSS) 2010/11. The relationship between poverty and migration was measured with the help of Ordinary Least Square (OLS) regression model whereas socio-economic status of the households was measured with the help of Chi square analysis. The finding indicated that access of piped drinking water, modern toilet facilities, access the radio/tape, mobile/telephone, land ownership, average months of food sufficiency and average per capita consumption expenditure was better for the (any member) migrant's households compared to non-migrant's households. Based on this poverty line, it was derived that around 34 percent households fall below the poverty line. The incidence of poverty was higher for the non-migrants' households compared to any member migrants' households.
\end{abstract}

Key word: Poverty, Household, Nepal, Migration, Remittance

\section{Background to the Study}

Migration and poverty have become critical development issues in the contemporary world. Migration is the both cause and consequence of poverty. In some parts of the world, poverty may be a root cause of migration under certain condition, whereas in other parts, under different conditions, the poor will be among the last to move. In some areas, migration may be the way to walk out of poverty while in others it contributes to an extension of poverty. The inter-relation is made complex because both terms, "migration" and "poverty", are difficult semantically: both are intuitively obvious but, in practice, have proved notoriously difficult to define and to measure accurately (Skeldon, 2003).

Migration affects the income and expenditures of migrant's households and consequently affects poverty. The effect of migration on per capita household income is equal to the difference between remittances obtained and the income of the household member(s) earned before migrating. The economic advantage gained through migration is not necessarily restricted to the individual migrant. In fact, the financial links individual migrants

Corresponding author: Ramesh Prasad Adhikari, Faculty Associate of Padma Kanya Multiple Campus, Tribhuvan University, Kathmandu and Research Co-coordinator of Transcultural Psychosocial Organization (TPO) Nepal, E-mail: rameshadhikaria@gmail.com. 
maintain with their families in areas of origin are well documented and remittances are considered instrumental in increasing the welfare of the households (Sahlins, 1974).

Migration is a driver of growth and an important route out of poverty with significant positive impacts on people's livelihoods and well-being. People move from one place to another place in search of a better life. Migrants are both pushed by lack of opportunities at home places and pulled by the hope to gain economic opportunities, employment and services in the new areas. The movement of the people from rural to urban areas represents a significant livelihood strategy for poor. Temporary migration is perceived as a way of maximizing the family's income and minimizing its risks (Stark, 1985). The remittances sent by the international migrants are also contributing to poverty reduction of the households as well as to improve the local and national economy of a nation (Anh, 2003).

In the present time, international migration has received more attention of the people than that of internal migration. However, internal migration is also equally significant in terms of the proportion of people involved and the share of remittance on poverty reduction. The internal migration especially rural-urban migration can bring significant change for the development of society (Anh, 2003). Ping (2003) draws attention on internal labor migration for development of China and says, "Without migrants there would be no Beijing, Shanghai, Guangzhou or Shenzhen". Both internal and international migrations are integral parts for the process of development with the help of alleviating poverty (Chirot and Reid, 1997).

Several studies have been conducted to identify the impact of migrant's remittance on poverty reduction in the world. However, in case of Nepal, very few studies have been conducted to identify this relationship. These studies are also based on descriptive study. Some researchers have found no causal relationship between migrant's remittances and poverty (Acharya, 2001, Chhetry, 1991, KC, 2003).

The census 2001 shows that 13.2 percent of the total native-born population was the lifetime migrant at the district level and 3.4 percent of the total population was emigrants from Nepal. In 2011, around 25 percent of the households have at least one member absent or living outside the country (CBS, 2012). Likewise, the Nepal Living Standard Survey (NLSS) I, II and III (1997/98, 2003/4 and 2010/11) indicated that the incidence of household poverty has declined sharply during the interval period (CBS, 19982004 and 2011). These studies also indicate that the main reason behind it was due to the remittances obtained for the households from both internal and international migration. In the present time, the government of Nepal and international development agencies has shown great interest in this area. In such situation, this study tries to fulfill the gaps and identifies the relation between migrant's remittances and its impact of household's consumption by using 3,000 households' data from six districts of Nepal.

\section{Theoretical Bases of the Study}

The relationship between migration and poverty was analyzed based on three school of thoughts; optimistic, pessimist and livelihood approach. During the period 1950s and 1960s, optimistic (developmentalist and neoclassical) school of thought argues that remittances have positive effects on poverty reduction of the receiving areas. This school of thought focus that remittance is the important factor for increasing living standards and economic condition of the poor without considering whether the remittances are used for consumption, buying house or other investment (Zachariah et al., 2001; Koc, 2004; Adams, 2005; World Bank, 2007, Acosta et al., 2007). Contrary to the optimistic views, the pessimistic school of thought argued that remittances have negative effect on poverty. This school of thought believed that remittances are only used for 
daily survival but not in productive activities. In such situation, there is no impact of remittances on development and poverty reduction (Cohen, 2005, Seddan, 2004, Martinez, 2004, Goldring, 2004, Urzua, 2000 and De Haas, 2006).

Table1

Theoretical explanation of the relationship between migration and poverty

\begin{tabular}{|c|c|}
\hline Theoretical approaches & Focus of this approaches \\
\hline $\begin{array}{l}\text { 1.Optimists } \\
\text { (Develop-mentalist and neo classical view) } \\
\text { (Before 1973) }\end{array}$ & $\begin{array}{l}\text { - } \text { Capital and knowledge transfer } \\
\text { - Improve livelihood and survival of families } \\
\text { - Support the development of the community and nation. } \\
\text { - Invest large sums of money in enterprises } \\
\text { - The re-allocation of labour (Todaro 1969:139) }\end{array}$ \\
\hline $\begin{array}{l}\text { 2. Pessimist } \\
\text { (historical structure and dependency view) } \\
(1973-1990)\end{array}$ & $\begin{array}{l}\text { - Migration withdrawal the human capital and make more dependence (Adams } \\
\text { 1969) } \\
\text { - Increases the inequalities in communities of origin (Lipton 1980) } \\
\text { - Remittance was mainly spent on conspicuous consumption } \\
\text { (Lipton 1980) } \\
\text { - Remittance was unstable and temporary sources of revenue (Hayes 1991). } \\
\text { - Migration as the process of penetration of capitalist and it is the causes of } \\
\text { development of underdevelopment (Frank 1966). }\end{array}$ \\
\hline $\begin{array}{l}\text { 3. Pluralist perspectives (New economic of } \\
\text { labour migration and livelihood approach) } \\
\text { (1980s and1990s) }\end{array}$ & $\begin{array}{l}\text { - As response of optimists and pessimists views of migration } \\
\text { - It offered both positive and negative links of migration and development } \\
\text { - Migrants' remittance serves as income insurance for households of origin (Lucas } \\
\text { and Stark 1985) } \\
\text { - Potential sources of investment capital for the migrants households at the time of } \\
\text { imperfect credit and risk. } \\
\text { - Livelihood strategy to overcome various market constraints, productive } \\
\text { investment and improvement of the livelihood of the households (Taylor et al. } \\
\text { 1996) }\end{array}$ \\
\hline
\end{tabular}

The concept of new economic of labor migration and livelihood approaches emerged in 1980 and 1990s based on both optimistic (neo-classical theory) and pessimistic (structuralist) views of migration. This school of thought focuses that the migrants' remittances have both positive and negative effects for development process. The scholars argued that migration could be considered as a livelihood strategy to overcome various market constraints, potentially enabling households to invest in productive activities and improve their livelihoods. The migration is seen as a part of broader household livelihood strategy to diversify income sources and overcome social, economic and institutional development constraints in places of origin (McDowell and de Haan 1997, Scoones 1998, De Haan 1999 and Ellis 2000). However, the impact of migration on poverty and well-being varies widely according to context. Some households may benefit from migration, but other may experience further impoverishment or move into poverty (Kothari, 2002). This study was analyzed based on the livelihood approaches; migration has both positive and negative impact on household poverty.

\section{Data and Method}

The Poverty Alleviation Fund (PAF) Follow-up household survey: 2010/11 data set is the major source of data for this study. Central for Economic Development and Administration (CEDA) conducted the survey in six districts (Humla, Jumla, Rolpa, Doti, Dailekh and Rauthat) for the World Bank. The survey covered the latest per capita consumption expenditure, socio-economic status, and migration and remittance situation of the households. This survey adopted two stage quasi-randomized sampling design. In the first stage, the wards 
were selected based on the prevalent proportion of size; the selected wards were termed as primary sampling unit (PSU). In the second stage, 15 households for each sample wards were selected by using systematic random sampling procedure. In total, 200 PSUs were selected, of which 18 were from Humla, 20 from Jumla, 32 from Rolpa, 32 from Doti, 36 from Dailekh and 62 from Rauthat. The total sample size of the households in these six districts was 3000. To examine the incidence of consumption poverty of the any member migrant households (experimental groups) and non-migrant's households (control groups), this study adopted quasi-experimental research design. To identify the relationship between poverty and migration, Ordinary Least Square (OLS) regression model was used and the socio-economic status of the households was measured with the help of Chi square analysis.

\section{Theoretical Basis of the Measurement of Poverty}

In this study, poverty is measured following the procedure employed by Nepal Living Standard Survey (NLSS) 2010/11. The NLSS derived the consumption poverty line by using the Cost-of-Basic-Needs (CBN) method. At first, a nutrition norm of per capita 2,220 kcal per day was determined based on the minimum caloric requirements of different age and gender groups and the composition of an "average" Nepali household. Second, 37 food items for which units and prices were available were selected and their quantities consumed by the households were determined. Third, the cost of this bundle was determined by using mean unit values for these goods in different area of Nepal. This basket turned out to cost Rs. 11,929 per person per annum. Likewise, the expenditure of the non-food item was calculated based on the average differences between total expenditure and expenditures on the 37 food items. Finally, adding the average amount Rs 7,332 for non-food items, the final poverty line was calculated to be Rs. 19,261 per person per annum in real prices (CBS, 2012).

In this study, the consumption poverty line derived by NLSS 2010/11was used. Based on the variation of regional price of index, different poverty line was derived. Finally, the relationship between poverty and migration was examined by using Ordinary Least Square (OLS) regression model. The model of study is as follows;

$$
\mathrm{Y}=\alpha+\beta_{\mathrm{MH}} \mathrm{X}_{\mathrm{MH}}+\varepsilon_{\mathrm{i}}
$$

$\mathrm{Y}$ represents the average per capita total consumption (food and non-food) expenditure of the households and the $\mathrm{X}_{\mathrm{MH}}$ was the dummy variable represents the households having migrant members. Likewise, $\alpha$ is known as the intercept at which the line cuts the $\mathrm{x}$-axis and $\beta_{\mathrm{MH}}$ is the slope of line and it referred as the regression coefficient of $\mathrm{y}$ on $\mathrm{x}$. The migration status $\left(\mathrm{X}_{\mathrm{MH}}\right)$ was the major factor that influences the consumption expenditure of the households (Y). The coefficient of $\mathrm{X}_{\mathrm{MH}}$ explained the effect of having migrant members in the households on per capita consumption expenditure of the households relative to not having migrant member of the households. $\varepsilon$ i denotes the random error that represents the influence of other factors on Y.

\section{Findings}

\section{Demographic status of the households}

The total population was 19,997 from the 3,000 study households. The sex ratio 105.9 indicated that the male population was slightly higher than female population. The average family size was 6.7 . The total dependency ratio of the study population was 90.2, which was higher for the non-migrant households (105.9) than that of any member migrant households (77.0). 
The share of active age population (15-59 age groups) was higher for any member migrant's households than that of non-migrant's households. However, in case of dependent population (age 0-14 and 60 and above), the share was higher for the non- migrant households. Regarding the distribution of the sample household's population by caste/ethnicity, majority of the households population were found to be Brahmin/Chhetri (49.7\%) and it was followed by Janjati (22.4\%), Dalit (21.8\%) and others (6.2\%) respectively.

Table 2

Demographic characteristic of the households by migration status

\begin{tabular}{|c|c|c|c|}
\hline \multirow{2}{*}{ Particulars } & \multicolumn{2}{|c|}{ Household } & \multirow{2}{*}{ Total } \\
\hline & Migrant & Non-migrant & \\
\hline \multicolumn{4}{|l|}{ Population } \\
\hline Male & 52.9 & 50.0 & 51.4 \\
\hline Female & 47.1 & 50.0 & 48.6 \\
\hline \multicolumn{4}{|l|}{ Age structure of population } \\
\hline$\%$ of population aged $0-14$ years & 37.3 & 43.9 & 40.6 \\
\hline$\%$ of population aged $15-59$ years & 56.5 & 48.7 & 52.6 \\
\hline$\%$ of population aged $60 \&$ above & 6.3 & 7.3 & 6.8 \\
\hline \multicolumn{4}{|l|}{ Caste/Ethnicity } \\
\hline Brahmin/Chhetri & 45.0 & 54.3 & 49.7 \\
\hline Janjati & 25.3 & 19.5 & 22.4 \\
\hline Dalit & 22.1 & 21.4 & 21.8 \\
\hline Others & 7.7 & 4.8 & 6.2 \\
\hline $\mathrm{N}$ & 9920 & 10077 & 19997 \\
\hline \multicolumn{4}{|l|}{ Marital status (age 5 and above) } \\
\hline Married & 52.7 & 48.7 & 50.7 \\
\hline Unmarried & 43.0 & 45.0 & 44.0 \\
\hline Widowed & 3.6 & 5.3 & 4.4 \\
\hline Divorce/separated/deserted & 0.8 & 1.1 & 1.0 \\
\hline $\mathrm{N}$ & 8648 & 8635 & 17283 \\
\hline Total Dependency Ratio & 77.0 & 105.9 & 90.2 \\
\hline Sex ratio & 112.1 & 100.1 & 105.9 \\
\hline Average family size & 7.4 & 6.1 & 6.7 \\
\hline
\end{tabular}

\section{Households facilities}

Household facilities include types of house, sources of drinking water, sources of light, access of modern toilet, and ownership of radio/tape, television and mobile/telephone. The proportion of Pakki households was higher for non-migrant households. The relation between types of house and the household having migrant member was not statistically significant $\left(\chi^{2}=1.13, p>0.01\right)$. Access of piped drinking water was better for migrant households compared to non-migrant households and this relation was statistically significant $\left(\chi^{2}=16.07, p<0.01\right)$. The facility of electricity was better for migrant households. However, the relation was not statistically significant $\left(\chi^{2}=0.48, \mathrm{p}>0.01\right)$. Around 16 percent of the migrant households had modern toilet facilities while 15.4 percent of non-migrant households had modern toilet facilities. The facilities of modern toilet also depended on migration status of the households. 
The facilities of radio/tape, television and mobile/telephone were better in any member migrant households compared to non-migrant households. The access of radio/tape, television and mobile/telephone of the households was significantly determined the migration status of the households.

Table 3

Households facilities by migration status

\begin{tabular}{|c|c|c|c|c|}
\hline \multirow{2}{*}{ Households facilities } & \multicolumn{2}{|c|}{ Household } & \multirow[t]{2}{*}{ Total } & \multirow{2}{*}{$\begin{array}{l}\text { Chi-square } \\
\text { Values and level of significant }\end{array}$} \\
\hline & Migrant & Non- migrant & & \\
\hline \multicolumn{5}{|l|}{ Types of house } \\
\hline Pakki (Cemented) & 13.8 & 16.5 & 15.3 & \multirow{2}{*}{$1.13^{* *}$} \\
\hline Others (Non pakki and kachhi) & 86.2 & 83.5 & 84.7 & \\
\hline \multicolumn{5}{|l|}{ Sources of drinking water } \\
\hline Piped drinking water & 55.7 & 48.3 & 51.6 & \multirow{2}{*}{$16.07 * * *$} \\
\hline Other (hand pump, well, river, pound stream) & 44.3 & 51.7 & 48.4 & \\
\hline \multicolumn{5}{|l|}{ Sources of light } \\
\hline Electricity & 20.3 & 19.3 & 19.8 & \multirow[t]{2}{*}{$0.48 * *$} \\
\hline Others (Kerosene, Solar, Tukimara, Diyalo, Oil) & 79.7 & 80.7 & 80.2 & \\
\hline \multicolumn{5}{|l|}{ Toilet facilities } \\
\hline Modern toilet & 16.3 & 15.4 & 15.8 & \multirow[t]{3}{*}{$5.36^{* * *}$} \\
\hline Traditional toilet & 9.6 & 12.3 & 11.1 & \\
\hline No toilet & 74.1 & 72.3 & 73.1 & \\
\hline \multicolumn{5}{|l|}{ Radio/Tape } \\
\hline Yes & 47.3 & 42.3 & 44.5 & \multirow{2}{*}{$7.43 * * *$} \\
\hline No & 52.7 & 577 & 55.5 & \\
\hline \multicolumn{5}{|l|}{ Television } \\
\hline Yes & 10.7 & 7.2 & 8.8 & \multirow{2}{*}{$11.19 * * *$} \\
\hline No & 89.3 & 92.8 & 91.2 & \\
\hline \multicolumn{5}{|l|}{ Mobile/Telephone } \\
\hline Yes & 33.2 & 24.1 & 28.2 & \multirow[t]{4}{*}{$30.13 * * *$} \\
\hline No & 66.8 & 75.9 & 71.8 & \\
\hline Total & 100.0 & 100.0 & 100.0 & \\
\hline $\mathrm{N}$ & 1343 & 1657 & 3000 & \\
\hline
\end{tabular}

$(* * *=$ statistically significant and $* *=$ not significant at 0.01 level $)$

\section{Economic status}

Economic status includes land ownership and food sufficiency of the households, average per capita food consumption expenditure of the households. The inverted $U$ shape relationship between land ownership and household having migrant members of the household was statistically significant $\left(\chi^{2}=11.29, p<0.01\right)$. The proportion of food sufficiency households was higher for any member migrant households compared to non-migrant households and this relationship was statistically significant $\left(\chi^{2}=11.49, \mathrm{p}<0.01\right)$. The average months of food-sufficiency was 7 months for any member migrant households compared with 6.6 months for non-migrant households. The average per capita consumption expenditure (both food and non-food) was also better for migrant households. 
Table 4

Economic characteristics of the households by migration status

\begin{tabular}{|c|c|c|c|c|}
\hline \multirow{2}{*}{ Economic characteristics } & \multicolumn{2}{|c|}{ Household } & \multirow[t]{2}{*}{ Total } & \multirow{2}{*}{$\begin{array}{l}\text { Chi-square } \\
\text { Values and level of significant }\end{array}$} \\
\hline & Migrant & Non-migrant & & \\
\hline \multicolumn{5}{|l|}{ Land ownership } \\
\hline Yes & 98.5 & 96.6 & 97.4 & \multirow{3}{*}{$11.29 * * *$} \\
\hline No & 1.5 & 3.4 & 2.6 & \\
\hline $\mathrm{N}$ & 1343 & 1657 & 3000 & \\
\hline \multicolumn{5}{|l|}{ If yes, area of land } \\
\hline Less than 1 Ropani & 9.5 & 9.4 & 9.4 & \multirow{5}{*}{$0.04 * *$} \\
\hline 1-5 Ropani & 33.8 & 34.1 & 34.0 & \\
\hline More than 5 Ropani & 56.8 & 56.4 & 56.6 & \\
\hline Average land (in Ropani) & 8.8 & 8.9 & & \\
\hline $\mathrm{N}$ & 1300 & 1623 & 2923 & \\
\hline \multicolumn{5}{|l|}{ Food sufficiency status } \\
\hline Yes & 23.4 & 18.3 & 20.6 & \multirow{3}{*}{$11.49 * * *$} \\
\hline No & 76.6 & 81.7 & 79.4 & \\
\hline $\mathrm{N}$ & 1343 & 1657 & 3000 & \\
\hline \multicolumn{5}{|l|}{ If no, way to manage food } \\
\hline Loan and credit & 14.1 & 13.1 & 13.5 & \multirow{7}{*}{$0.51^{* *}$} \\
\hline Others (wage labor, sell property, less food) & 85.9 & 86.9 & 86.5 & \\
\hline $\mathrm{N}$ & 1029 & 1353 & 2382 & \\
\hline Average months of food sufficiency & 7.0 & 6.6 & 6.8 & \\
\hline Average per capita food consumption expenditure(Rs.) & 18289 & 17009 & 17589 & \\
\hline Average per capita non-food consumption expenditure(Rs.) & 14878 & 11987 & 13281 & \\
\hline Average per capita total consumption expenditure(Rs.) & 33167 & 28996 & 30863 & \\
\hline
\end{tabular}

$(* * *=$ statistically significant and $* *=$ not significant at 0.01 level $)$

\section{Incidence of Poverty by migration status of the household}

The different poverty line of NLSS 2010/11was used to measure consumption poverty of the study households. In case of Humla and Jumla, the poverty line was Rs. 19,859. Similarly, for Rolpa, Dailekh and Doti, the poverty line was Rs. 16355; and Rs. 17540 for Rauthat (NLSS, 2010/11). Based on the poverty line, 33.8 percent households fall below the poverty line. It also suggests that the incidence of poverty was higher for non- migrant households (35\%) compared to any member migrants households $(32.3 \%)$

Table 5

Incidence of consumption poverty for the migrant and non-migrant households

\begin{tabular}{llll}
\hline \multirow{2}{*}{ Poverty status } & \multicolumn{3}{c}{ Household status } \\
\cline { 2 - 4 } & Non-migrant & Migrant & Total \\
\hline Below poverty line & 35.0 & 32.3 & 33.8 \\
Above poverty line & 65.0 & 67.7 & 66.2 \\
$\mathrm{~N}$ & 1343 & 1657 & 3000 \\
\hline
\end{tabular}

The household having any migrant members was introduced as the main predictor variable of the per capita consumption expenditure of the households in this regression equation. In this model, non-migrant 
household was taken as reference category. Hence, the coefficients on another category (any member migrant's households) explained the effect of migration of any family member on per capita consumption expenditure of the households relative to non-migrants' households. The regression model shows that per capita consumption expenditure of any member migrants' households had more Rs. 4171 (significant at $<0.01$ ) compared with non-migrants households. This factor explained 0.5 percent (significant at $<0.01$ ) of the variance in the per capita consumption expenditure of the households.

Table 6

Regression coefficients: dependent variable per capita consumption expenditure

\begin{tabular}{lllll}
\hline Model & $\mathrm{B}$ & Std. error & $\mathrm{T}$ & Sig. \\
\hline Constant & 28996 & 697.3 & 41.6 & 0.000 \\
Any member migrants & 4171 & 1042.2 & 4.0 & 0.000 \\
$\mathrm{R}^{2}$ & 0.005 & & & \\
\hline
\end{tabular}

\section{Discussion and Conclusion}

In particular, migrants' remittances can be a significant factor in alleviating poverty of rural households. Remittances from urban employment supplement rural incomes, boost consumption in rural areas, contribute to household savings and thus can stimulate the local economy. The growing numbers of domestic and international migrants, who secure work and send remittances back home, have a profound effect on many socio-economic issues in Nepal.

The sustainable livelihood approach suggests that migration is a key livelihood diversified and survival strategy for poor and non-poor households in many parts of the developing world (de Haan, 2002). The study found that migrant households have better access of land holding, average per capita food and non-food consumption, access to piped drinking water, electricity and modern toilet facility, access of radio/TV and mobile was similar to finding obtained from Hampshier, 2002.

The land ownership of the household determines the households' abilities (Reardon, 1997). Adam (1993), found the inverted $U$ shape relationship between land ownership and the migration of any member of the households. This study also found the same inverted $U$ shape relationship between land ownership and household having migrant members.

The incidence of poverty identified by this study (33.8\%) was higher than that of NLSS 2010/11 (25.2\%). These 6 districts are within 25 most deprived districts out of 75 districts of Nepal based on the composite development indices developed by the Central Bureau of Statistics (CBS). PAF selected the survey VDCs based on the proportion of poor women, Dalit, Janajati and vulnerable groups so this could be another reason for high incidence of poverty in the study households (PAF, 2007).

NLSS I, II and III (1997/98, 2003/4 and 2010/11) indicate that the incidence of household poverty decline sharply during the interval period and the major reason behind it was due to the remittance obtained for the households from both internal and international migration. Similar to Maharjan and colleagues (2013) and Housen and colleagues (2013), the finding of this study suggests that incidence of poverty is lower for the any member migrant households as compared to non-migrant households. The statistical analysis also suggests that there was positive relationship between any member migration and the per capita consumption expenditure of the households. 
Although the background characteristics such as age-sex, education, duration, destination of migration have significant impact on the level of remittance and consumption expenditure of the households, this study only analyzed the per capita consumption of the member migrants or non-migrants households without considering the background characteristics of the migrants. The study has established positive impact of any member migrants of the households on average per capita consumption of the households in the study area. The statistical analysis indicate that the migrant households have better access to assets (Physical, social and financial) for livelihood and the incidence of poverty was higher for the non-migrants households compared to any member migrants households. Several scholars have also stated that the incidence of poverty was higher for the non-migrant's households compared to any member migrant's households (WB, 2007). Therefore, from this study it can be concluded that the remittance sent by the migrants both within and outside the country had significant contribution to increase the average per capita consumption of the households and ultimately reducing the incidence of poverty in the selected districts. Migration and remittances are important processes through which low-income households can escape from poverty. Hence, the government can develop the national poverty reduction strategies through integrating the strong migration policies. Migration needs to be understood from a livelihoods perspective and policies need to be designed through multidisciplinary and multi-sector study and analysis.

\section{References}

Acharya, Laxmi Vilas. (2001). Intregation of Population in Poverty Alleviation Programmes in Nepal, In Bal Kumar KC (ed.), Population and Development in Nepal, Vol. 8. Kathmandu: Central Department of Population Studies, Tribhuvan University.

Acosta, P., P. Fajnzylber, and J. Lopez. (2007). The Impact of Remittances on Poverty and Human Capital: Evidence from Latin American Household Surveys. World Bank Policy Research Working Paper, 4247. World Bank, Washington, DC.

Adams, R. \& Page, J. (2005). Do International Migration and Remittances Reduce Poverty in Developing Countries?. World Development Vol.33 No.10. Great Britain.

Adams, R.H. (1993). The Economic and Demographic Determinants of International Migration in Rural Egypt. Journal of Development Studies 30 (1).

Anh, D.N. (2003). Migration and poverty in Asia: with reference to Bangladesh, China, the Philippines and Viet Nam, Ad hoc expert group meeting on Migration and Development, organized by the Economic and Social Commission for Asia and the Pacific, Bangkok, 27-29 August.

Central Bureau of Statistics. (2000). Nepal Living Standard Survey 1998/99. Kathmandu: Central Bureau of Statistics.

Central Bureau of Statistics. (2004). Nepal Living Standard Survey 2003/04. Kathmandu: Central Bureau of Statistics.

Central Bureau of Statistics. (2012). Nepal Living Standard Survey 2010/11. Kathmandu: Central Bureau of Statistics.

Chhetry, Devendra. (2002). Population, Development and Poverty in Nepal: An Integrated Approach of Analysis, In Bal Kumar KC (ed.), Population and Development in Nepal, Vol. 10. Kathmandu: Central Department of Population Studies, Tribhuvan University.

Chirot, D. and A. Reid. (1997). Essential Outsiders: Chinese and Jews in the Modern Transformation of Southeast Asia and Central Europe. Seattle, University of Washington Press.

Cohen, J. (2005). Remittances Outcomes and Migration: Theoretical Contests, Real Opportunities Studies in Comparative International Development. Spring 2005. Vol. 40.

De Haan Arjan. (1999). Livelihoods and Poverty: The Role of Migration - A Critical Review of the Migration Literature. Journal of Development Studies 36 (2).

de Haan, Arjan. (2002). Migration and Livelihoods in Historical Perspective: A Case Study of Bihar, India. Journal of Development Studies 38 (5).

De Haas, H. (2006). Migration, remittances and regional development in Southern Morocco. International Migration Institute, University of Oxford, United Kingdom.

Ellis, Frank. (2000). The Determinants of Rural Livelihood Diversification in Developing Countries. Journal of Agricultural Economics 51 (2). 
Goldring, L. (2004). Family and Collective Remittances to Mexico: A Multi-dimensional Typology. Development and Change vol. 35(4). Institute of Social Studies, Blackwell Publishing, USA.

Hampshire, Kate. (2002). Fulani on the Move: Seasonal Economic Migration in the Sahel as a Social Process. Journal of Development Studies 38 (5).

Housen, Tambri; Hopk, Sandra ins \& Earnest, Jaya (2012). Internal Remittances on Poverty and Consumption in Developing Countries: Implications for Policy, Population Space Place 19, 610-632 (2013)

KC, Bal kumar. (2003). Migration, poverty and development in Nepal paper presented on Economic and Social Commission for Asia and the Pacific, Ad Hoc Expert Group Meeting on Migration and Development, 27-29 August 2003, Bangkok.

Koc, I \& Isal, O. (2004). International Migrants' Remittances and Welfare Status on the Left-Behind Families in Turkey. International Migration Review, spring 2004. Vol 38, Issue 1.

Kothari, Uma. (2002). Migration and Chronic Poverty. Chronic Poverty Research Centre, Working Paper No 16. Institute for Development Policy and Management, University of Manchester.

Lanjouw, Peter, Giovanna Prennushi, and Salman Zaidi. (1996). Building Blocks for a Consumption-Based Analysis of Poverty in Nepal. mimeograph, World Bank, Washington, D.C. (1996).

Martinez, M. (2004). The Remittance Lifeline, Hemisphere. A Magazine of the Americas, Fall 2004. Vol.14.

McDowell, C. and A. de Haan. (1997). Migration and Sustainable Livelihoods: a critical review of the literature. IDS Working Paper no. 65

Maharjan, Amina, Bauer, Siegfried and Knerr, Beatrice (2013), International Migration, Remittances and Subsistence Farming: Evidence from Nepal, International Migration Vol. 51 (S1) 2013, ISSN 0020-7985

Poverty Alleviation Fund (PAF), (2007). Monitoring and Evaluation Baseline Survey 2007, unpublished report submitted by Central Department of Population Studies (CDPS) Tribhuvan University Kirtipur

Ping, H. (2003). China migration country study, Paper presented at the Regional Conference on Migration, Development and Pro-Poor Policy Choices in Asia, organized by the Bangladesh Refugee and Migratory Movements Research Unit, Bangladesh/DFID UK, Dhaka, 22-24 June.

Reardon, T. (1997). Using Evidence of Household Income Diversification to Inform Study of the Rural Nonfarm Labor Market in Africa. World Development, Vol.25, No.5.

Sahlins, M. (1974). Stone Age Economics. London, Tavistock.

Scoones, Ian (1998). Sustainable Rural Livelihoods: A Framework for Analysis. IDS Working Paper 72. Brighton: IDS.

Seddan, D. (2004). South Asian remittances: implications for development. Contemporary South Asia, Vol. 13(4). Carfax Publishing.

Skeldon Ronald. (2003). Migration and Poverty, Paper presented at the conference on African Migration and Urbanization in Comparative Perspective, Johannesburg, South Africa, June 4 - 7, 2003.

Stark, O. and David Bloom. (1985). The New Economics of Labour Migration. American Economic Review, 75(2).

Urzua, R. (2000). International migration, social science and public policy. International Social Science Journal, Vol.52. Issue 165.

World Bank. (2007). Albania: Urban growth, migration and poverty reduction. A poverty assessment Report No. 40071. World Bank.

Zachariah, K.C., Mathew, E.T., Rajan, S. (2001). Social, Economic and Demographic Consequences of migration on Kerala. Uruguay International Migration. Vol.39. Issue 2. 